\title{
Aspects on Budgeting
}

\section{S. Praveen Kumar, R. Ramamoorthy,Banupriya}

\begin{abstract}
According to Institute of Chartered Management Accountants (ICMA) England "A plan qualified in monetary term prepared and approved prior to a defined period of time usually showing planned income to be generated and or to be incurred during that period and the capital to be employed to attain a given objective"
\end{abstract}

Keywords : ICMA,PLAN,Chartered management

\section{INTRODUCTION}

A budget is a quantitative expression of a plan of action relating to the forthcoming budget period. It represents a written operational plan of management for the budget period." A plan expressed in money. [1],[3],[5] It is prepared and approved prior to the budget period and may show income, expenditure, and the capital to be employed, may be drawn up showing incremental effects on former budgeted or actual figures, or be compiled by zero based budgeting". Budget and Budgetary control. The terms budget and budgetary control are often used interchangeable to refer to a system of managerial control. Budgetary control implies the use of a comprehensive system of budgeting to aid management in carrying out its functions like planning, co-ordination and control.

\section{A. BUDGET:}

According to Institute of Chartered Management Accountants (ICMA) England "A plan qualified in monetary term prepared and approved prior to a defined period of time usually showing planned income to be generated and or to be incurred during that period and the capital to be employed to attain a given objective". [1],[3],[5]

\section{B. BUDGETORY CONTROL:}

The Chartered Institute of Management Accountants (CIMA) London defines budgetary control as establishment budget relating to the responsibility of executives to the requirement policy and the continuous comparison of actuals with budgeted results either to secure individuals action the objective of policy or to provide a basic for its revision.

A budget is the monetary and quantitative expressions of business plans and policies to be pursued in the future period of time the term budgeting is used for

\footnotetext{
Revised Manuscript Received on July 22, 2019.

DR S. Praveen Kumar Director, Department of Management Studies, Bharath Institute of Higher Education \& Research Email: praveenkumar.mba@bharathuniv.ac.in

R.Ramamoorthy Department of Management Studies, Bharath Institute of Higher Education \& Research,Tamilnadu,India Email: ramamoorthy0071@gmail.com

Banupriya, ,student Department of Management Studies, Bharath Institute of Higher Education \& Research,Tamilnadu,India Email:banupriya@gmail.com
}

preparing budgets and other procedures for planning co-ordination and control of business enterprise. Budgetary control is the process of determining various budgeted figures for the enterprises for the future period and then comparing the budgeted figures with the actual performance for calculating variations, if any first of all budgets are prepared and then actual results are recorded. [7], [9] ,[11]

\section{OBJECTIVE OF THE STUDY}

To know plastics industry profile.

To know company profile of Sujala Pipes Pvt. Ltd. Company.

To study the budgeted estimates and accruals of the revenue expenditure and revenue receipts.

To study the variations of the accruals from the budgeted estimates.

To study the working of the financial department at Sujala Pipes Pvt. Ltd. Co. [8],[ 10] ,[12]

\section{NEED OF THE STUDY}

- To know about the budget and budgetary control of a "SUJALA PIPES PVT LTD." Company.

- To know about the status of a company by different financial Budgetary policies.

- To know about the present scenario of plastic companies Investment estimation that are existed in the market.

- To know about the present impact of budgetary control on the Financial position of the company.

- To know about the fast performance to based on future Estimation of the budgetary control of the techniques. [8],[10],[12]

\section{SCOPE OF THE STUDY}

The scope of the study limited to collecting the data published in the reports of the company and opinions of the employees of the organization with reference to the objective stated above and theoretical framework of the data. With a view to suggest solutions to various problems relating to budget and budgetary control. [14],[ 16], [18]

\section{V.LIMITATIONS}

$>$ The study is purely based on the information provided by the company and the data is collected form the reports, annual reports, magazines of the company.

$>$ To study is restricted to Sujala Pipes Pvt. Ltd. Co.

$>$ To study is restricted to limited period. 


\section{Aspects on Budgeting}

\section{METHODOLOGY OF THE STUDY}

Research is the systematic investigation of fact that seeks to establish relationship between two types.

\section{Primary data:}

- Officers of accounts sections.

- Executives and staff of financial and accounts department.

- Meeting with concerned people.

- Personal observation.

\section{Secondary data:}

- Annual reports of Sujala Pipes Pvt. Ltd. Co.

- Financial management text books.

- Printed Materials.

- Journals and magazines

- News papers.

CALCULATION OF REVENUE RECEIPTS BUDGET FOR THE YEAR 2004-2005

\begin{tabular}{|c|c|c|c|c|}
\hline S.Nolo & DESCRIPTION & BUDGETED & ACTUALS & VARLANCE \\
\hline 1. & Sales and other receipts & $60,66,25,179$ & $55,14,77,436$ & $5,51,47,743$ \\
\hline 2. & Other Income & $35,96,102$ & $32,69,184$ & $3,26,918$ \\
\hline \multirow[t]{2}{*}{3.} & Increase in Inventory & (-) $1,59,33,057$ & (-) $1,44,84,597$ & (-) $14,48,460$ \\
\hline & Total & $59,42,88,224$ & $54,02,62,023$ & $5,40,26,201$ \\
\hline
\end{tabular}

\section{Interpretation:}

In this year it can be seen that every item actuals are bellow the budget estimate which reprehensions a positives indications of savings, the actuals are beyond budget estimates due to revision in pay scales. Which can be ignored, because in total budget estimates are more then the actuals

In revenue receipts, the actuals are below the budgeted. Except in increase in inventory value is negative. The budget estimates with a good variation percentage. [19],[21],[23]

CALCULATION OF REVENUE EXPENDITURE BUDGET FOR THE YEAR 2005-2006

\begin{tabular}{|l|l|l|l|l|}
\hline SNQ & DESCRIPTION & BUDGETED & ACTUALS & VARLANCE \\
\hline 1. & Sales and other receipts & $40,68,80,342$ & $36,98,91,220$ & $3,69,89,122$ \\
2. & Other Income & $28,00,738$ & $25,46,126$ & $2,54,612$ \\
3. & Increase in Inventory & $(-) 7,807$ & $(-) 7,098$ & $(-) 709$ \\
& & & & \\
& & & & \\
\hline & Total & $40,96,73,273$ & $37,24,30,248$ & $3,72,43,025$ \\
\hline
\end{tabular}

\section{Interpretation:}

In this year, the budgeted are above the actuals. Material consumed is high value the budget estimates among all items and in total that shows a good budgeting effort makes the actuals. [20], [22], [24]

In revenue receipts, the budgeted are above the actuals, but with a minimum percentage of variation as compared with previous year.
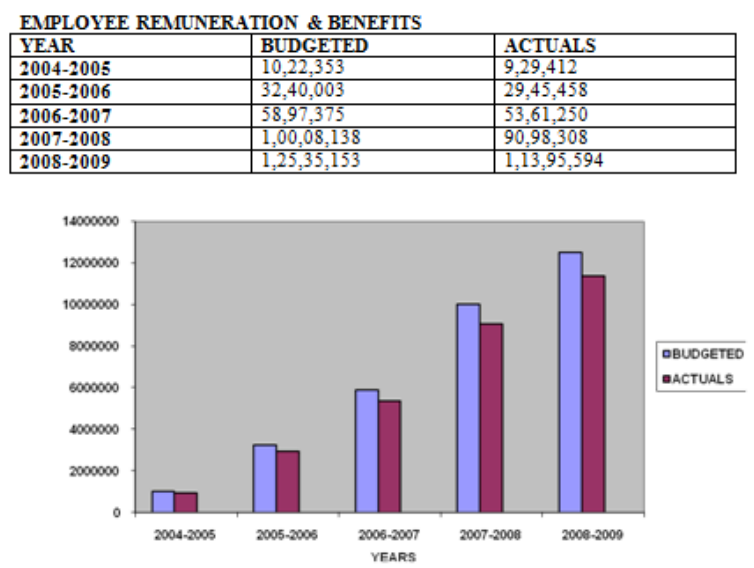

CALCULATION OF REVENUE RECEIPTS BUDGET FOR THE YEAR 2007-200\$

\begin{tabular}{|l|l|l|l|l|}
\hline S.NQ & DESCRIPTION & BUDGETED & ACTUALS & VARIANCE \\
\hline 1. & Sales and other receipts & $79,43,88,636$ & $72,21,71,487$ & $7,22,17,149$ \\
2. & Other Income & $28,95,385$ & $26,32,169$ & $2,63,216$ \\
3. & Increase in Inventory & $(-) 2,73,515$ & $(-) 2,48,650$ & $(-) 24,865$ \\
& & & & \\
\hline & Total & $79,70,10,506$ & $72,45,55,006$ & $7,24,55,500$ \\
\hline
\end{tabular}
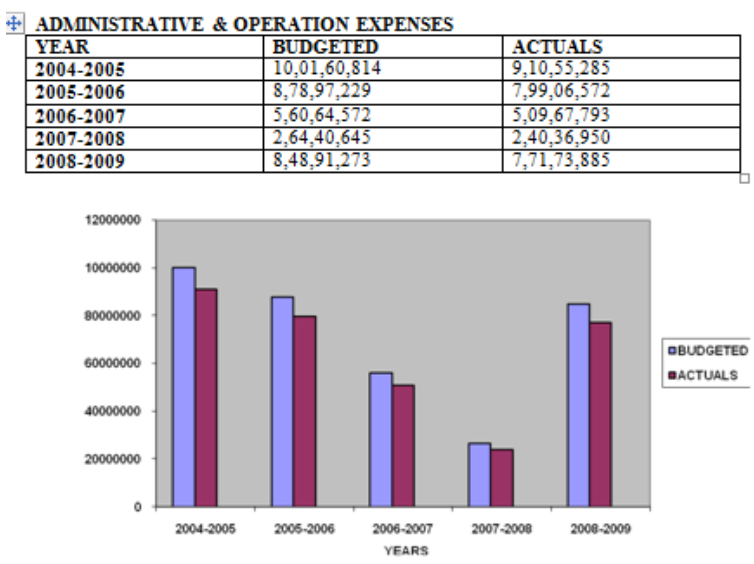


MANUFATURING EXPENSES
\begin{tabular}{|l|l|l|}
\hline YEAR & BUDGETED & ACTUALS \\
\hline $\mathbf{2 0 0 4 - 2 0 0 5}$ & $2,95,12,360$ & $2,68,29,419$ \\
\hline $\mathbf{2 0 0 5 - 2 0 0 6}$ & $2,74,36,923$ & $2,49,42,658$ \\
\hline $\mathbf{2 0 0 6 - 2 0 0 7}$ & $9,98,08,181$ & $9,07,34,710$ \\
\hline $\mathbf{2 0 0 7 - 2 0 0 8}$ & $8,40,70,526$ & $7,64,27,751$ \\
\hline $\mathbf{2 0 0 8 - 2 0 0 9}$ & $13,48,25,637$ & $12,25,68,761$ \\
\hline
\end{tabular}

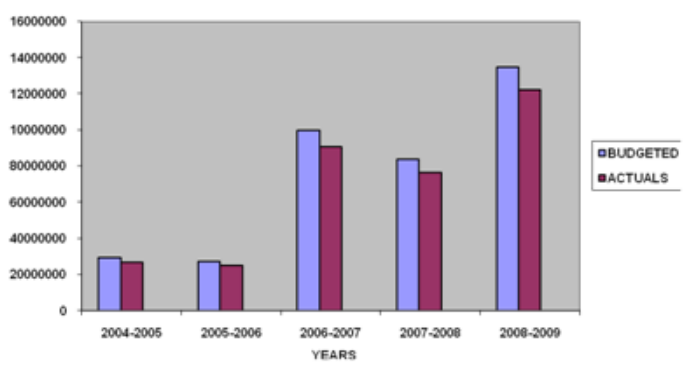

\$ DEPRECIATION
\begin{tabular}{|l|l|l|}
\hline YEAR & BUDGETED & ACTUALS \\
\hline $\mathbf{2 0 0 4 - 2 0 0 5}$ & $1,47,38,772$ & $1,33,98,884$ \\
\hline $\mathbf{2 0 0 5 - 2 0 0 6}$ & $1,78,56,564$ & $1,62,33,240$ \\
\hline $\mathbf{2 0 0 6 - 2 0 0 7}$ & $2,39,11,697$ & $2,17,37,907$ \\
\hline $\mathbf{2 0 0 7 - 2 0 0 8}$ & $2,27,69,641$ & $2,06,99,674$ \\
\hline $\mathbf{2 0 0 8 - 2 0 0 9}$ & $2,28,97,612$ & $2,08,16,011$ \\
\hline
\end{tabular}

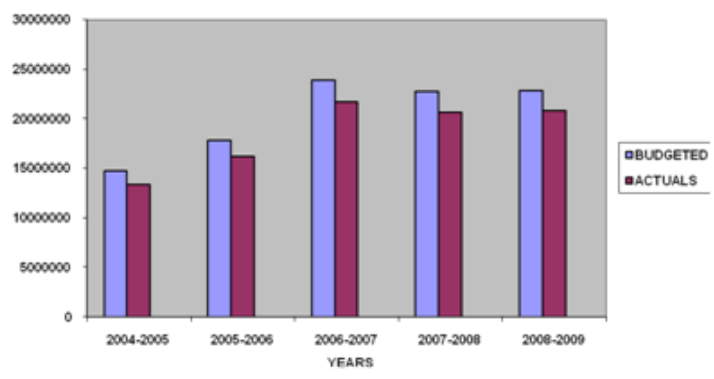

VII. RESULTS

- The budget and budgetary control of Sujala Pipes Pvt. Was found to be very effective when considered all categories of items.

- In spite of having techniques many techniques of budget system, the company is not following any of the system to control budgeter's.

- .In the 2004-2005 the total budgets value was high. Where was in the next two years it has come down drastically. [31],[33]

- In all the five years budget expenditure was of high consumption a value.

- Material consumed which is one of the inputs for the production.

- It is also found that the reasons for maintaining huge stock of manufacturing expenses in 2005-2006 is due to high production of manufacturing expenses as well as the sales is also high in the year of 2006-2007 compared to other year.

\section{DISCUSSION}

- It is recommended to the company that every item to be considered when categorizing the items into budgets.

- As company is not using any budget techniques we can suggest the company to follow budget techniques for better and effective budget and budgetary control.

- Pre audit of all expenditure proposals before issue of order and to check whether the expenditure is legitimate, approved by appropriate authority and availability of funds for the above items.

- The budget estimations should be made that they will reach with the actuals for every year with very less variation.

- In Sujala revenue expenditure and revenue receipts are not interdependent on each other.

- The revenue expenditure will be spent based on the production target irrespective of the revenue receipts.

- In this proves the effective financial performance of budget department in the organization

\section{CONCLUSIONS}

Since, all the production units in Sujala Pipes Pvt. Ltd. Will run perpetually through out the year, there will be minimum variations in the revenue expenditure budget estimates and actuals. As the expenditure will be incurred more or less to the estimations made by the organization. [25],[27],[29]

In concern with overhead expenses, it will also be with minimum variations between budget estimates and actuals. Since the production process will be consistent. Any change in the items of expenditure, will lead to the review in the budget estimates by the accounts and finance department. It is also suggested to the company that budget techniques will be very useful to control and manage cost effectively. [25],[27],[29]

\section{REFERENCES}

1) BharthVajan R., Ramachandran S.,Psychographic dimensions of training,2016,International Journal of Pharmacy and Technology,V-8,I-4,P-23727-23729

2) Balakrishnan P., Bharthvajan R.,A study on human resource planning in hospitals in Chennai City,2014,International Journal of Applied Engineering Research,V-9,I-22,P-7503-7507

3) Priyadarsini P., Bharthvajan R.,Role of emotional intelligence training programme in reducing the stress of the nurses,2014,International Journal of Applied Engineering Research,V-9,I-22,P-7411-7421

4) Kerinab Beenu G., Bharthvajan R.,Empirical analysis on the cosmetic buying behavior of young women in South India,2014,International Journal of Applied Engineering Research,V-9,I-22,P-7361-7366

5) Balakrishnan P., Bharthvajan R.,Whistling in the wind,2014,International Journal of Applied Engineering Research,V-9,I-22,P-7586-7593

6) Krishnan B., Peter M.,Health hazards of Indian Bpo employee-an alarming issue,2014,International Journal of Applied Engineering Research,V-9,I-22,P-7336-7341

7) Kerinab Beenu G.H., Peter M.,Role of insurance in economic development,2014,International Journal of Applied Engineering Research,V-9,I-22,P-7532-7539

8) Balakrishnan P., Peter M., Priyadarsini P.,Efficiency of safety measures for wellbeing of employees in manufacturing industry,2014,International Journal of Applied Engineering Research,V-9,I-22,P-7376-7382

9) Anbarasi M., Praveen Kumar S.,Online sales promotions of herbal products and its effectiveness towards tanisha.com,2019,Indian Journal of Public Health Research and Development,V-10,I-1,P-195-200

10) Anbarasi M., Praveen Kumar S.,Various online marketing and promotions strategies to improve the validation towards the organic products in the pharmaceutical sectors, 2019,Indian Journal of Public Health Research and Development, V-10,I-1,P-263-269

11) Loganathan R., Praveen Kumar S.,Grievance handling a key factor for solving issues of employees in an organization,2014,International Journal of Applied Engineering Research,V-9,I-22,P-7483-7491

12) Loganathan R., Praveen Kumar S.,Study on preference of private label brands in super and Hypermarkets,2014,International Journal of Applied Engineering Research,V-9,I-22,P-7327-7335

13) Smitha M., Praveen Kumar S.,Understanding stress and its managementamong the nurses in 


\section{Aspects on Budgeting}

Chennai city,2014,International Journal of Applied Engineering Research,V-9,I-22,P-7560-7565

14) Kerinab Beenu G.H., Praveen Kumar S.,A study on the investment behavior of Chennai investors in mutual fund schemes,2014,International Journal of Applied Engineering Research,V-9,I-22,P-7520-7525

15) Loganathan R., Praveen Kumar S.,Retention strategies key for organizational productivity,2014,International Journal of Applied Engineering Research,V-9,I-22,P-7443-7447

16) Pavithra J., Ganesan M., Brindha G.,State wise analysis of microfinance sector in India,2016,International Journal of Pharmacy and Technology,V-8,I-4,P-23417-23432

17) Pavithra J., Ganesan M.,A comparative study on microfinance in India and abroad,2016,International Journal of Applied Business and Economic Research,V-14,I-8,P-5471-5476

18) Pavithra J., Ganesan M.,A study on awareness and impact of micro-financial schemes,2016,International Journal of Applied Business and Economic Research,V-14,I-8,P-5449-5460

19) Senthilmurugan P., Pavithra J.,Consumer preference towards organised retailing with reference to Big Bazaar,2014,International Journal of Applied Engineering Research,V-9,I-22,P-7469-7475

20) Senthilmurugan P., Pavithra J.,Implication of social media marketing in growing healthcare industry,2014,International Journal of Applied Engineering Research,V-9,I-22,P-7448-7456

21) Loganathan R., Pavithra J.,Consumer perception towards private labe brand over other brands in super markets and hypermarkets,2014,International Journal of Applied Engineering Research,V-9,I-22,P-7355-7360

22) Kerinab Beenu G., Pavithra J.,Tradeâ€“off between liquidity and profitability in logistics industry,2014,International Journal of Applied Engineering Research,V-9,I-22,P-7398-7401

23) Kerinab Beenu G., Pavithra J.,A study on the prospective consumerâ $€^{\mathrm{TM}_{S}}$ perception towards utility cars in Chennai city,2014,International Journal of Applied Engineering Research,V-9,I-22,P-7526-7531

24) Pavithra J., Dilli Babu P., Ambuli T.V.,A study on budgetary control at Maruti Service Masters, Chennai,2014,International Journal of Applied Business and Economic Research,V-12,I-2,P-151-161

25) Pavithra J., Dilli Babu P., Ambuli T.V.,A study on customer satisfaction of retro Garments Pvt Ltd, Chennai,2014,International Journal of Applied Business and Economic Research,V-12,I-2,P-381-391

26) Kerinab Beenu G.H., Pavithra J., Senthilmurugan P.,A study on the influence of promotional activities for TATA ARIA among consumers in Chennai,2014,International Journal of Applied Engineering Research,V-9,I-22,P-7572-7578

27) Vijayaragavan S.P.,An investigative expert that's general FBG sensors,International Journal of Mechanical Engineering and Technology,V-8,I-8,PP-1500-1505,Y-2017

28) Vijayaragavan S.P.,Equalization routing protocol for Wi-Fi sensor strategy,International Journal of Mechanical Engineering and Technology,V-8,I-8,PP-1662-1666,Y-2017

29) Karthik B., Kiran Kumar T.V.U., Vijayaragavan P., Bharath Kumaran E.,Design of a digital PLL using 0.35 $\hat{\mathrm{I}}^{1} / 4 \mathrm{~m}$ CMOS technology,Middle East Journal of Scientific Research,V-18,I-12,PP-1803-1806,Y-2013

30) Kanniga E., Selvaramarathnam K., Sundararajan M.,Kandigital bike operating system,Middle - East Journal of Scientific Research,V

31) Jasmin M., Vigneshwaran T., Beulah Hemalatha S.,Design of power aware on chip embedded memory based FSM encoding in FPGA,International Journal of Applied Engineering Research,V-10,I-2,PP-4487-4496,Y-2015

32) Jasmin M.,Optimization techniques for low power VLSI circuits,Middle East Journal of Scientific Research,V-20,I-9,PP-1082-1087,Y-2014

33) Jasmin M., Vigneswaran T.,Fuzzy controller for error control of on - Chip communication,2017 International Conference on Algorithms, Methodology, Models and Applications in Emerging Technologies, ICAMMAET 2017,V-2017-January,I-,PP-1-5,Y-2017

\section{AUTHORS PROFILE}

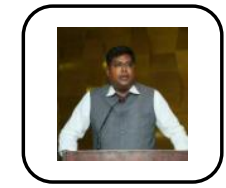

DR S. Praveen Kumar Director, Department of Management Studies, BIHER

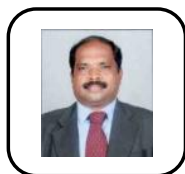

R.Ramamoorthy Assistant Professor Department of Management Studies, Bharath Institute of Higher Education \& Research,Tamilnadu,India

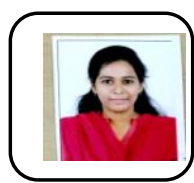

Banupriya, student Department of Management Studies, Bharath Institute of Higher Education \& Research,Tamilnadu,India 